\title{
CONSTRUINDO NO COTIDIANO DE SOBREVIVÊNCIA DA FAMÍLIA - UMA OPÇÃO EM ENFERMAGEM COMUNITÁRIA
}

\author{
FAMILY'S DAILY SURVIVAL - AN OPTION IN NURSING COMMUNITY
}

Zulene Maria de Vasconcelos Varela ${ }^{1}$

\begin{abstract}
RESUMO: Narra o cotidiano de pessoas carentes em busca da sobrevivência. Observou-se que a fome é o estímulo acionador de todo o processo de buscar das pessoas e é motivado pelo sonho de Vencer na vida. Os obstáculos são a falta de escolaridade, de qualificação para o trabalho, dificuldade de verbalização das necessidades. As facilidades são o corpo pronto para o trabalho, a auto - confiança, a fé em Deus e esperança na ajuda das pessoas. Na caminhada a pessoa toma decisões, age, sonha que um dia há de vencer na vida. 0 "Caminhando" e o "Encontrando" podem fazer emergir as falas do "Eu - interior" despertando a pessoa para a vivência do ser-no-mundo-com-os-outros-seres e com as coisas, na possibilidade de caminhar na autenticidade do ser, segundo a linguagem de Heidegger. No grupo em estudo identificaram-se três modos de caminhar na vida: no sentido da autenticidade, da inautenticidade e da possibilidade do vir-a-ser. Observando-se a espacialidade do caminhar identificou-se a rede social de apoio de cada participante.
\end{abstract}

PALAVRAS CHAVE: Família; Enfermagem comunitária; Cotidiano de saúde/sobrevivência.

\section{INTRODUÇÃO}

A autora e as preocupações que originaram a pesquisa

Sendo eu enfermeira de saúde pública, o que aqui se descreve é a representação que faço do cotidiano sob a optica da enfermagem, 2,14,17,18,19 atuando com pessoas, famílias e grupos em uma área socialmente desprotegida.

A dinâmica social, com os percalços que deterioram o poder aquisitivo das pessoas e geram desempregos, fez emergir os clientes que em um determinado momento motivaram este trabalho - famílias pobres chefiadas por mulheres, poucos homens (jovens ou adultos) presentes à família, muitas crianças, gente idosa, na busca da sobrevivência compartilhando um estilo de vida que caracteriza um segmento social em Fortaleza (Ceará-Brasil). ${ }^{15}$

A escolha do título deve-se à preocupação em objetivar um estilo de vida que se caracteriza pela busca diária do dinheiro para comprar o alimento para a família. Faz-se a representação do estilo de vida percebido pela enfermeira no contexto espaço-temporal de 1 ano em uma favela. Esse aglomerado populacional vive para comprar a comida que consome, numa busca que os consome dia-a-dia, sem no entanto se extinguir, neles, a esperança em dias melhores.

Os autores que me ajudaram na fundamentação de minhas intervenções e reflexões foram SaintArnaud, ${ }^{15}$ Habermas, ${ }^{12}$ Heidegger. ${ }^{10,11}$ Os conceitos de gênero e de cultura foram encontrados em fontes variadas. ${ }^{1,5,6,8,9} \mathrm{~A}$ compreensão sobre a dinâmica do cotidiano foi assimilada de Berger e Luckman. ${ }^{3} \mathrm{~A}$ morbidade no grupo estudado estimulou-me a ler Melo Filho. ${ }^{13}$

\section{O QUE DELES OUVI E COM ELES APRENDI}

Aqui, reúnem-se as falas de alguns dos membros da amostra. Intercalo as minhas. Falo com meus pensamentos a respeito de seu modo de ser-no-mundo-com-os-outros. ${ }^{10}$

Professora Titular do Departamento de Enfermagem - Universidade Federal do Ceará / Coordenadora do Grupo FAMEPE. 
Nas falas percebe-se a esperança como "esperar dias melhores", "esperar o marido chegar com o dinheiro para comprar o almoço", "esperar que os filhos cresçam para poder pedir a separação ao marido" ou "para poder buscarem emprego fora de casa", ou, ainda, "esperar o aumento do salário para..."

PARA VENCER NA VIDA é um texto construído com a fala de um dos dois homens adultos que integraram a amostra. A maioria das famílias tem a mulher como chefe.

"Para vencer na vida é preciso ter estudo e ter um ofício; há ofícios que dão mais dinheiro que outros; há ofícios que a gente faz porque é o jeito, mas às vezes, dá vergonha".

"A gente pode aprender um ofício, uma profissão só de olhar outro fazendo. A pessoa começa como servente numa construção; vai olhando como fazer a mistura do cimento com o cal; daí a pouco se mete e faz o serviço. Depois, aprende a subir uma parede até ser capaz de construir uma casa. Para fazer isso não é preciso ter estudo, mas é preciso mostrar pro mestre que sabe fazer o que ele pede para ser feito, faz direito, não brinca no serviço e merece confiança".

"Quem não tem estudo, pega trabalho duro; quem tem estudo pode pegar trabalho mais "manero" (trabalho leve) e chegar a subir na vida e realizar os sonhos que tem desde muito tempo."

"É preciso fazer de tudo para não ficar parado. Se trabalhando, já é pouco, imagine ficando "parado". 0 dinheiro mal dá para comprar comida e pagar a conta da bodega (mercearia). Fica sempre para o outro mês. Aí vem a escola dos meninos, o remédio, os livros e cadernos, o ônibus para ir pro trabalho."

"A gente se arranja como pode. A família toda se vira; faz uma coisa, outro faz outra para ajudar. Se não for assim, ninguém consegue comer; só não trabalham os pequenos. Eles ajudam em casa".

"O que se come todo dia é arroz, feijão, pão, café; é só pro que o dinheiro dá. Tempero (carne ou outra proteina animal), como se diz, só quando sai dinheiro. Às vezes, a galinha. 0 mais barato, mesmo, é o ovo com farinha. Tem dia que é só arroz com feijão".

\section{O SER-COM-O-OUTRO NO COTIDIANO ${ }^{10}$}

0 texto que segue é a reunião de fragmentos de falas que evidenciam o jeito de ser das pessoas com quem convivi, ao se relacionarem com os acontecimentos e com as pessoas no cotidiano da sobrevivência. Percebe-se o preconceito, mas, também, a solidariedade humana.

"D. Fulana é como se fosse minha mãe". Dizia isso Neusa referindo-se a uma senhora a quem sempre recorria em caso de necessidade. Neusa queria convidar essa senhora para ser madrinha do filho que nascera.

"Vou batizar meu filho no próximo domingo e queria que a senhora fosse ser a madrinha". A senhora respondeu: "P or que não convida alguém de sua família? Uma de suas irmãs ficaria contente". "Ah! Não! Elas são mais pobres que eu...", argumentou Neusa.

(...) O fulano disse que aquele menino ali (aponta o dedo para um menino que passa) é "bicha" (homoss exual). Entre eles, mesmo pobres e moradores da favela, identificavam-se as diferenças e os diferentes eram apontados.

No espaço territorial em que convivem, no "pedaço" existem, segundo eles, os maus e os bons elementos.

“E u não ando com maus elementos. (...) Eu não sei se meus filhos fumam maconha ou tomam drogas. Na minha frente, não fumam não; mas, como andam com maus elementos...". A polícia vive dando batida por lá procurando bandido..." (fala de Lemos).

As crianças dizem: "Quero ser polícia". Para quê? Perguntei.

"Para pegar bandido". Voltei a perguntar: "Você já viu algum bandido?" Ele disse: "J á, sim! Eles puxam faca, batem nos outros e vão para a cadeia". "Quero ser atirador." "Atirar para que?" Pergunto eu. "Para pegá bandido!"

D. Carlita estava de resguardo do oitavo filho e era uma boa mãe, uma mulher trabalhadora e responsável. 0 filho de 18 anos precisou ir ao hospital; sentia uma forte dor no peito, de uma queda que levara. "A vizinha ofereceu-se para levá-lo".

Já a filha de 12 anos, grávida de um jovem que fugira para não ser responsabilizado, não recebia os merecidos cuidados. D. Carlita explicou quando perguntei sobre o fato. "Eu não tenho condições de ir com ela para o pré-natal e ela não quer ir! Ela é mulher e toda mulher sabe como se cuidar." 
Uma criança, conversando comigo, falou assim, quando perguntei:

0 que você quer ser quando crescer?

"Quero ser homi"

Quando ficar "homi" o que quer fazer para ganhar dinheiro?

"Quero pegá minino"

Por que você quer pegar "minino" quando ficar "homi"?

"Ora, prá ser como meu pai".

Seu pai pega menino?

"Pega, lá no centro" (Centro da Cidade).

Por que seu pai pega menino lá no Centro?

"Num sei!...(0 pai dele é policial)

Conversando com Lemos 40 anos. "O senhor não tem medo de andar por aí, sem documento? (Ele havia perdido todos, há alguns anos):

"Não senhora. Polícia conhece marginal; só de olhar, só pela cara, pelo jeitão". Eu nem ando com arma e nem com droga!... J á os meus filho (os homens), não ouvem conselhos, andam com quem não presta... Um desses fins de semana. F. saiu com o dinheiro da semana no bolso e voltou sem nada. Me disse que a polícia "cismou" com ele. Para não ir prá cadeia, deu dinheiro para o policial".

Houve um momento em que conversava com muitos jovens e crianças do sexo masculino. Mas, mudaram-se para outros bairros ou cidades. Percebe-se que as famílias de melhor nível de escolaridade e com filhos maiores, não permanecem muito tempo morando em favelas. Logo que podem procuram outro local para moradia. Restaram dois rapazes.

Os dois jovens, explicando porque mais uma vez interrompiam os estudos:

"É porque lá só tem mau elemento. Vivem armando briga. A professora não tem moral!...".

Percebi que há três grupos de rapazes: o grupo que não sai de casa e passa a semana trabalhando, de alguma forma, e tem uma família que mantém laços afetuosos entre os membros; cedo encontram uma garota com quem se casam ou entram em união consensual. Um outro grupo, que embora não seja formado por infratores da Lei, se envolve com a polícia por embriaguez e desordem e convive mais de perto com os drogados. 0 terceiro grupo é composto por aqueles apontados pelos moradores da favela como sendo bandidos com história de furto, roubo, estupro.

Percebi que o espaço territorial, embora partilhado pelos três grupos e suas famílias, tem fronteiras bem delimitadas pelo estilo de vida. Esse estilo de vida mostra evidências de acordos interpessoais explicitados ou não. No momento em que um desses acordos é rompido há uma reorganização do espaço territorial e dos grupos; alguém se torna "bandido" ou "mocinho"; ou, quando não se coloca em nenhuma das duas categorias opta por ser amigo do "bandido ou do mocinho".

As crianças da favela do (...) quando crescem, querem ser policiais para pegar bandido. 0 policial é atirador e impõe respeito e admiração. "O policial é bom, o bandido é mal". 0 bandido saiu daquele meio e 0 policial também. As crianças, inconscientemente, buscam reproduzir em suas vidas, por imitação, o poder do bandido e o poder da autoridade. Em sua fragilidade e natural tendência à imitação de modelos significativos para si, vêem em ambos, a força, o poder. Um dia serão como eles e não mais temerão nada, nem ninguém. Os outros é que terão medo deles.

As crianças e jovens que se encontram e convivem com infratores da Lei são manipuladas dentro desse mundo do crime. 0 mundo do crime tem atrativos. Nele se envolvem de forma direta ou indireta, pessoas próximas por laços de consagüinidade, por amizade, por vizinhança, por necessidade financeira ou, ainda, pela visão ingênua sobre poder. Os líderes desse mundo podem ser vistos, ouvidos, imitados, temidos e procurados. Por isso eles podem manipular pessoas simples e vulneráveis à ação da persuasão, da força e do envolvimento circunstancial. As pessoas mais vulneráveis à ação deletéria desses "maus elementos" são as crianças e os jovens adolescentes de ambos os sexos. A seguir narra-se um fato que ilustra o que ficou dito.

Duas crianças conquistaram a simpatia de funcionários de determinada repartição pública; passaram a tomar conta do estacionamento e a lavar os carros quando thes era solicitado pelos proprietários. Um deles, surpreendeu o roubo de algo que estava dentro de um dos carros e conseguiu identificar o ladrão. Como o ladrão, embora menor de idade, era mais forte, conseguiu correr com o roubo e ainda empurrou uma das crianças, liberando o caminho para a fuga. A criança contou o ocorrido e ainda disse que sabia de quem se tratava. A partir 
desse dia, os garotos não mais puderam vir ganhar o pão-de-cada-dia, como o faziam há muitos meses, para ajudar família.

No dia seguinte, tive a surpresa de saber que as crianças foram ameaçadas pelo jovem ladrão:

"Se a polícia me pegar, eu pego vocês; se falarem alguma coisa, eu pego vocês...".

Perguntei: "Você acha que o seu amigo devia ter contado ou ficado calado?" O garoto respondeu: "Devia ter contado; eu também contava se fosse ele. Porque senão iam pensar que foi ele que robou. Mas ele contou e agora pode até levar uma surra do que roubou". Perguntei: 0 que você acha que a gente pode fazer para que não aconteça nada de ruim com seu amigo? O garoto respondeu: "Ora, é só dá alguma coisa pro cara. Se a senhora dé a ele, ele num faz nada". Continuei o diálogo, perguntando: E você acha certo uma pessoa roubar uma coisa e ainda ganhar dinheiro para não fazer nada com a gente? A resposta veio rápida: "Não, mas é assim que os caras faz. Ele mora vizim a gente e vive roubando mas nunca pegam ele..."

A convivência com os fatores de risco e as poucas alternativas para se livrar, ou para se proteger contra o perigo real, gera medo. Esse medo expresso não é um sentimento infundado, irreal. 0 menino fala do que vê ocorrer e dá as soluções - submeter-se "comprando" ao "bandido", o direito de viver em paz ou, recorrendo à polícia, para que se prenda o bandido.

Os jovens são obrigados a conviver com o medo, o conflito, a insatisfação de não poderem morar longe daquele lugar; têm de evitar sair à noite, ou evitar voltar sozinhos tarde da noite. E, dado o "confinamento" no bairro, desconhecem formas de acesso a cursos profissionalizantes.

\section{REDE COMUNITÁRIA DE SUPORTE SOCIAL}

Festinger, ${ }^{7}$ em sua teoria da dissonância cognitiva, enfatiza a função do grupo social, considerado por ele tanto fonte de dissonância como também mecanismo importante em sua redução. A experiência de identificar e rastrear uma rede de apoio formada por mulheres reforça o que se descreve em seguida.

$\mathrm{Na}$ localidade onde mora Sara consegui rastrear um processo de rede. Ela é moradora nesse conjunto há mais de 20 anos. Sara, concluiu o $2^{\circ}$ grau, casou, teve uma filha.

Ao se separar do marido, sentiu-se mais à vontade para fazer cursos aperfeiçoando-se como artesã. A procura de seus trabalhos foi crescendo, o que a fez se sentir cada vez mais segura de que realmente possuía a ferramenta para a sobrevivência.

A clientela que consumia seus produtos passou a fazer parte de seus cursinhos de artesanato. À proporção que melhorava a renda familiar com a nova habilidade, as pessoas retornavam à professora para troca de receitas, moldes e para reciclagem. A partir desse intercâmbio consolidou-se o primeiro círculo que passou a gerar novos outros círculos. Armarinhos com material para o artesanato foram aparecendo; esses armarinhos passaram a comprar o produto gerado pelas artesãs locais e a empregar mão-de-obra da circunvizinhança.

Esses grupinhos, que se mantinham em contínua interação, transformaram-se em grupos de apoio recíproco. Um dos maiores benefícios por mim percebido foi o de se constituir audiência para as queixas contra os maridos, liberando-as de tensões acumuladas. A maioria dessas mulheres encontrava no trabalho manual, não somente fonte de renda pessoal, mas uma forma de fugir à rotina doméstica, incluindo nesta, os relacionamentos patológicos. A figura central continuou sendo Sara. A necessidade de ter uma fonte de renda pessoal foi o móvel primeiro. Mas, o que a manteve no rumo inicial e possibilitou aprimoramento e ampliação de idéias foi a teia de relações que se formou envolvendo-a com pessoas e famílias que se diziam agradecidas pelo que ela lhes dera: uma ocupação, um lazer, uma fonte de renda, uma oportunidade de falar sobre o que thes ia na alma e na cabeça. $E$, mais que tudo, o chegar a grande descoberta de que seus problemas não eram algo pessoal, mas comum a outras mulheres, a outras famílias; que o problema pode nem estar dentro de casa, mas fora e serem relacionados a fatores que fogem ao controle de pessoas isoladas e ingênuas.

Marilena Chauí, ${ }^{5}$ em seu livro Conformismo e resistência, expõe depoimentos de mulheres e os analisa sob a optica da resistência. São mulheres, donas-de-casa, participantes ativas de movimentos reivindicatórios no interesse de questões próprias do mundo feminino. Era uma forma de resolver a dissonância: saírem de casa, mantendo-se dentro do padrão de papéis femininos - ajudar a família. Essa saída legítima de casa, permite à mulher modificar as coordenadas tempo-espaço domésticos, o que favorece a exposição a fatores que estimulam a tendência à atualização de seu ser. ${ }^{15}$ 


\section{AS CRENÇAS E O CUIDADO COM A SAÚDE ${ }^{11}$}

Uma aluna, em visita domiciliar, encontrou a dona da casa com um ferimento contuso na cabeça, o que Ihe produzia sangramento e, segundo a aluna, necessitava de sutura. A mulher negava-se a ir à emergência hospitalar, enquanto a aluna insistia em levá-la. No momento em que ocorrera o "acidente", o marido, um "pai de santo", estava em "transe". Neste estado atirou um instrumento ponteagudo na mulher, ferindo-a. Realmente, segundo ela, não fora ele o culpado. Ela não queria que ele fosse responsabilizado injustamente. Ela não queria envolver o marido com a polícia. O marido, na condição de "pai de santo" estava incorporando uma "entidade".

\section{AS QUESTÕES DE GÊNERO, A VIOLÊNCIA E A SAÚDE DA MULHER ${ }^{6,9,11,13,17}$}

As mulheres também se queixam da pressão exercida sobre sua vida sexual reprodutiva. "Mãezinha, outro filho? Não acha que já está bom de parar?"Essas frases se repetiam sempre que uma multípara procurava o pré-natal. Neusa ficou com vergonha e nunca mais apareceu para o pré-natal. A temática, a cada novo encontro com o pessoal dos serviços de saúde é os métodos contraceptivos. Essa pressão se estende ao local de trabalho, onde são muitas vezes levadas à condescendência forçada, ${ }^{15}$ que chega ao cúmulo de, em certos casos, a o lado do prato do almoço, estar a pílula anticoncepcional. Quando não essa estratégia, o que a mulher trabalhadora ouve é a formal exigência de que pratique o controle de natalidade; em alguns casos, a exigência de que provem que se submeteram à laqueadura de trompas.

Mas, o pior de todas as pressões, é aquela que emerge da realidade do cotidiano, a que é sentida no próprio organismo, a que toca a sensibilidade através do olhar, do ouvir a realidade, da falta de saneamento básico, de moradia, de emprego fixo, de salário certo e condigno, de acesso fácil a serviços de saúde, à escola; é a desnutrição, a insegurança sob todos os aspectos, o medo da doença incapacitante, do envelhecer e não poder mais ganhar o sustento; enfim, de problemas gerados pela conjuntura sócio-econômica, política e ideológica que foge ao controle direto da pessoa. 0 que mais atinge as mulheres da amostra é 0 aumento do gás, pão, café, açúcar, passagens de ônibus, feijão, arroz, ovos, galinha, luz.

Os fatores de desagregação sociais refletem-se na família gerando conflitos nas relações homem-mulher. As pressões do homem sobre a mulher recrudescem e se expressam por comportamento violento. Esse comportamento torna-se mais agressivo e insuportável, quando é acompanhado do alcoolismo, drogas, inserção no mundo criminal; ou, ainda, quando o homem "arranja outra" ou se envolve com farras de fim de semana desperdiçando o que conseguiu ganhar na jornada de trabalho passada, sem a certeza de conseguir assegurar o alimento da semana vindoura.

Uma das entrevistadas dizia que o companheiro nem trazia o sustento para a família e nem queria que ela trabalhasse fora de casa. Quando a coisa ficou insustentável, pressionada pela situação de fome, insegurança no dia de amanhã e pelo comportamento de finais de semana do companheiro, decidiu expulsá-lo de casa.

Esse tipo de pressão parece ser comportamento comum entre homens que usam a dependência financeira da mulher e a presença de filhos menores, como instrumento de pressão no atendimento de suas imposições. 0 homem não se sente na obrigação de providenciar alimento para os filhos quando abandona ou é mandado embora de casa. A mulher tem de mendigar-lhe a obrigação do sustento dos filhos, o que consegue em troca de concessões e de humilhação.

Uma das entrevistadas, D. J oana, auxiliar de enfermagem, ao ser abandonada pelo marido sentiu-se obrigada a deixar o emprego, porque não podia conciliar os plantões noturnos com os cuidados da filha menor. Ao deixar o emprego, passa a realizar atividades de enfermagem a domicílio, vendas de mudas de plantas (que mantém no quintal), de dindim (sorvete caseiro em saquinhos), trabalhos eventuais numa mercearia próxima de casa. 0 ex-marido "sustenta" ambas, (mãe e filha) porque, segundo ele diz para a filha do casal "sua mãe é uma mulher direita". Essa mulher, por medo de perder o sustento, faz tudo para que o ex-marido nunca mude de opinião a seu respeito.

Muitas mulheres não podem fazer o mesmo que D. J oana. 0 único meio é trancar a porta, dizer para as crianças não saírem e nem deixarem nenhum estranho entrar. A irmã mais velha, geralmente, fica tomando conta dos mais novos, fazendo a comida e cuidando da casa. 
No primeiro caso, a ansiedade gerada pelo fato de deixar a criança sozinha é reduzida ao abandonar o emprego. Mas, outros problemas passam a incomodar: a redução dos ingressos para a renda doméstica e a falta de um salário regular e garantido com vínculo empregatício e regalias correspondentes, tais como a aposentadoria e outras previstas na legislação trabalhista.

No segundo caso, a ansiedade e a culpa acompanham a mulher durante toda a jornada de trabalho, por imaginar os riscos a que ficam expostas as crianças.

0 processo de construção da sobrevivência pessoal e da família era uma luta solitária no grupo estudado. 0 ciclo inicia-se antes de o sol nascer e se completa quando todos dormem. 0 alimento é prioridade para o marido e os filhos; a prioridade maior é para quem traz o alimento ou dinheiro para casa. Para si, como mãe, serve qualquer coisa: pão, cafezinho, um cigarro, água e sempre em quantidade menor. Essa mulher que parecia sadia e forte apresentara, em diferentes ocasiões, hemorragias vaginais, dores de estômago, falta de sono, nervosismo, falta de ar, dores nas pernas, dermatoses alérgicas. Esses são os motivos pelos quais busca os serviços de emergências à noite, porque, de dia não tem tempo, não tem com quem deixar as crianças e tem o almoço para fazer. Os cuidados com a aparência pessoal, só quando todos dormem e acaba o serviço doméstico.

A iniciativa na relação sexual é sempre do marido, que não se preocupa se ela pode ou não engravidar, embora não goste que ela tome anticoncepcional. S egundo algumas opiniões, o homem gosta de ver a mulher grávida "para que não possa andar por aí paquerando"; dizem outras que o fato de as mulheres engravidarem freqüentemente é, para o marido, sinal de virilidade (macheza), ou que tem filhos porque pode mantê-los. Em alguns momentos, pareceu à autora que a multiparidade poderia estar relacionada à possibilidade de ampliar o número de pessoas que poderiam ajudar a família através dos laços do apadrinhamento dos filhos pelo batismo. A mulher que já gestara 7 vezes me falava do medo da velhice sozinha. Por isso era bom ter muitos filhos porque sempre poderia restar algum para cuidar dela na velhice. As famílias pobres convivem com 0 fantasma do óbito de crianças. Quando as crianças superam a idade de risco epidemiológico e atingem a adolescência, o óbito por causas externas continua a ceifar a prole dessas mulheres.

0 primeiro ponto de poder do qual a mulher pobre sabe tirar proveito prático, são os filhos - os filhos que ela criou sem grande participação do pai, serão agora, e, talvez, no futuro, apoio e proteção. É preciso, de agora em diante, mantê-los a salvo da influência nefasta do modelo paterno - egocêntrico, agressivo, autoritário, frustrado, vencido na luta pela sobrevivência e hostil em relação a ela, à mulher, que decidiu mudar de vida. $E$, como essa mudança inclui os filhos, é preciso que a mulher assuma a autoridade que antes pertencia ao marido. A menina assumirá os trabalhos domésticos em parte, ou totalmente; enquanto ela, a mulher sem companheiro, vai à luta. Logo que a filha cresça arranjará um marido que Ihe dará casa, comida; será uma boca a menos em casa. Espera também que o genro seja bom e ajude um pouco à sogra. Os meninos começarão a trabalhar fora, fazendo "biscates", até completar 18 anos e entrarem para o serviço militar.

A libertação do jugo masculino tem início quando assume os direitos sobre o próprio corpo e, em decorrência, pára de ter filhos, (faz "ligação"), torna-se frígida e já não se preocupa em lavar a roupa do companheiro e nem de aprontar-Ihe almoço e janta. Começa a sair de casa sob pretextos vários - reuniões na igreja, no posto de saúde, na associação de moradores. Busca trabalho fora de casa, relacionado com aquilo que lhe é mais familiar - serviços domésticos. Nesse momento depara-se com situações novas, próprias da evolução tecnológica, para a qual não se preparou.

O confronto com novas realidades, diferentes daquelas que constituíam seu cotidiano, até há pouco, Ihe deixara perplexa. Algo mudara dentro dela e no mundo em sua volta. Algo mudara em relação a lavar e passar roupa. Parava, aí, o conhecimento de Neusa, tornando presentes suas limitações para competir por um emprego bom com carteira assinada. Novamente, os filhos voltam à mente como o recurso à mão para a saída da crise. Retoma os trabalhos domésticos, e a filha mais velha vai em busca de trabalho como doméstica.

Enquanto uns poucos maridos aceitam a situação e outros abandonam a mulher e filhos para não mais voltarem, muitos não se conformam e passam a criar toda sorte de obstáculos à luta daquela mulher. A nova mulher, com novas cognições, já não sente o mesmo medo de antes. Coloca-se como pessoa que sabe não poder esperar mais nada dele. J á não quer voltar à vida de antes - de servidão e maus tratos.

Confrontos abertos se acirram. A violência, que antes era velada, mascarada, passa a ser transformada em violência física ou moral, espancamento. 0 homem dessa mulher não quer perder as prerrogativas de ser servido e obedecido, já que teve sempre mulher, casa, comida, roupa lavada e obediência a seus caprichos. A 
mulher, já sem o medo de antes e apoiada no exemplo de outras, em situação semelhante, busca a delegacia mais próxima e denuncia aquele homem, mesmo sabendo que pode estar arriscando a própria vida.

A maioria das mulheres da amostra, passou por esse processo e, quase todas, usavam a mesma expressão para indicar a nova vida: "não preciso de homem prá criá meus filhos."

\section{A MORADIA E O BAIXO PODER AQUISITIVO}

A mobilização espacial, por mudança de domicílio, é freqüente entre aquelas que vivem de aluguel. A autora manteve durante três meses reuniões semanais com um grupo de adolescentes que se dispersou por mudança de endereço - uma família mudou-se para São Paulo para ficar perto de parentes e tentar melhores condições de vida; outros para bairros distantes buscando aluguéis mais baixos; $B$ ia, não aguentando a cachaça do companheiro levou os quatro filhos consigo para viverem "um tempo", com o filho mais velho (do primeiro marido). Segundo comentários há costume de deixarem as casas ao final de curto período de tempo, sem pagarem o aluguel ou aguardarem o despejo judicial.

Sr. J oão contou à autora que não estava conseguindo pagar o valor novo do aluguel. Como ele não estava agüentando, teve de sair para a casa da cunhada, ele, a mulher e três filhos pequenos. Passavam o dia lá. À noite iam para a casa da mãe dele. Diz ele que não sabe, até quando vai viver assim, porque o trabalho na construção está cada vez mais difícil. Segundo alguns, o problema do baixo poder aquisitivo é tão sério que leva as famílias pobres a trocarem de domicílio de acordo com suas posses, até chegarem a um nível mais baixo de moradia em favelas, vilas em domicílios coletivos, em invasões, embaixo de viadutos.

\section{SOBREVIVÊNCIA E SAÚDE}

Entre pessoas, ditas carentes, o conceito toma diferente conotação sendo importante a idéia de corpo como instrumento de trabalho. Se o corpo consegue realizar um trabalho e este trabalho gera dinheiro ou reduz gastos pessoais, a pessoa acha que goza de saúde. Doença, então, assume o caráter de queixa percebida e manifestada no corpo (instrumento de trabalho), como obstáculo à realização do trabalho diário. Essas queixas geralmente são aquelas que caracterizam as emergências. Nas mulheres, emergências gineco-obstétricas, neuropsiquiátricas, psicossomáticas. ${ }^{13}$ Nos homens vêm associadas às violências, alcoolismo, acidentes de trabalho, à cultura de gênero. ${ }^{11}$ Por conta do critério de prioridade, que coloca os cuidados com a preservação e promoção da saúde em último lugar, observam-se problemas dentários, desnutrição, anemias ferroprivas, doenças parasitárias, visuais, auditivas, gastro-intestinais, dermatológicas, alérgicas, psicossomáticas, cardiológicas. Todos sem acompanhamento médico; o que se observa são as práticas alternativas - os chás, a ação da rezadeira, sessões de cura religiosa, auto-medicação. Na ocorrência de crises agudas incontroláveis é que o serviço de urgência é procurado.

Lucinda hospitalizara-se por causa de uma forte crise de nervos, embora apresentasse outros sintomas que, a princípio, indicava problema cardíaco. Após os exames, foram descobertos outros distúrbios de menor gravidade. Por conta deles, recebeu medicação e orientação para retornar após terminados os comprimidos. Acontece que, dias depois, já não havia mais nenhum comprimido. Ela os distribuíra entre as amigas com sintomas semelhantes aos seus. Fez isso, porque já se considerava muito bem de saúde e as vizinhas estavam precisando.

Lemos teve problemas com um ferimento na perna. Ele só lembrava de que um cachorrinho the mordera, uns dias antes. Como era um filhote de raça pequena, não se importou e nem tomou nenhum cuidado. Dias depois infectara. Sentiu febre, teve que se deitar e não pôde trabalhar. Mesmo orientado a procurar o serviço de saúde para atendimento especializado, satisfez-se com os cuidados prestados no domicílio e em saber que o cachorro era vacinado. Quando o vi novamente, trabalhando, sem problemas na perna, soube que fora curado pela "rezadeira".

Neusa costumava procurar a autora pedindo para ser levada à emergência do Hospital das Clínicas, à noite. Era sempre o mesmo: falta de ar, "agonia na cabeça, um acôcho no peito". Conversávamos, fazia um chá, ela melhorava. Sabia bem porque Neusa sentia tudo aquilo. 
FINALMENTE...

\section{O COTIDIANO QUE EU VI GEROU O CONHECIMENTO E AS IDÉIAS QUE ORA COMPARTILHO}

A enfermeira apreende a linguagem do corpo das pessoas que buscam a sobrevivência diária e se expõem aos riscos de adoecer e morrer diariamente:

- dos que buscam o prazer no corpo do outro e gestam;

- dos que buscam o prazer no corpo do outro e adoecem;

- dos que buscam o prazer no corpo do outro e não encontram.

A enfermeira apreende a realidade da família que se desagrega por causa das pressões da busca cansativa e rotineira do pão-de-cada-dia:

- O jovem busca o emprego e não encontra porque não tem idade, não é qualificado, não tem estudo;

- A mulher busca o serviço e encontra; efêmero e de baixo retorno financeiro, para saciar a fome de 7 a 10 bocas para vestir, calçar, colocar na escola para transportar-se para o emprego, para escola, para o médico...;

- O homem busca o emprego e não encontra o que quer;

- Busca, sofre, agride e se agride;

- Busca e para esquecer o sofrimento da busca se refugia na bebida e adoece e perde o gosto pela busca.

A Enfermeira aprende a realidade da família cuja mãe ficou só com os filhos para alimentar, vestir, mandar à escola.

- Fica só, e investe nos filhos, que passam a buscar emprego, um serviço qualquer e têm de deixar a escola.

- Fica só e já não consegue dormir, sente constante "dor-de-cabeça, nervoso, respiração pouca";

- Sente-se nervosa e fuma; o cigarro alivia a fome, faz esquecer muita coisa por alguns instantes.

A Enfermeira apreende a realidade dos jovens que buscam o prazer da festinha e se expõem:

- À agressiva "revista policial" em busca de conduta irregular, presença de droga, arma, ausência de documentos;

- A encontrar-se com o "mau elemento" que mora ali perto e lhe tira o que tem no corpo ou na carteira;

- Ao encontro e convívio com o álcool, drogas, arma branca ou de fogo. Do álcool e da droga para se "enturmar", "viajar" e "sonhar"; do uso de armas para se defenderem.

A Enfermeira apreende a realidade dos jovens que, não querendo se expor aos "maus elementos", não se "enturmam" e se sentem "diferentes".

Os riscos são tantos - risco de gestar, de ser pêgo pela polícia sem ser "marginal"; o risco de ser pêgo pelo marginal sem ser polícia ou sem ser mais forte; o risco de adoecer e não ter com que se tratar; o risco da água não tratada, do lixo e dejetos que estão por todos os lados.

Os riscos vêm também sob forma de pressão. Pressão para que façam coisas para as quais não estão "prontos" ou que não lhes interessam.

Os riscos são tantos e vêm sob tão variadas formas que as famílias de baixo poder aquisitivo preferem dizer: "seja o que Deus quiser", "vida de pobre é isso mesmo".

"Filho de rico é que nasceu prá ser dotô, um engenheiro..."

"Filho de pobre tem é que arranjá uma profissão".

E relaxam e riem e se divertem como podem e sobrevivem...

A E nfermeira apreende a realidade do jovem que virou homem e que vive com espontânea naturalidade, a descoberta do próprio corpo e sente suas exigências.

- Satisfaz seu desejo, se descobre pai, e traz para a casa da mãe a namorada, que virou mulher e mãe. 
A Enfermeira apreende a realidade da menina que, se descobrindo mulher, se encontra com o garoto que a faz mãe e é expulsa da casa dos pais.

Apreende a realidade da família que cresce, porque a mãe gesta, ao mesmo tempo em que acolhe a filha adolescente grávida, sem marido, e a "nora", também, grávida que não tem onde ficar.

A E nfermeira ouve a outra mãe dizer: "O rapaz que mexeu com a minha filha é doente não pode tê família. Ela mesmo não qué casá, diz que não qué tê vida qui nem eu".

A enfermeira ouve as crianças maiores dizerem:

"Quando eu crecê quero matá bandido. Quando eu crecê quero ser policial."

E se sabe que não há muita opção, ou será "mocinho" ou será "bandido", ou se refugiará no esquecimento da vida (na droga). Um dia descobre que ser polícia não vale a pena: prendem o bandido que logo mais será solto e passará a chantagear o "mocinho" que passa a temer, pela própria vida, e pela da família. Aí o "mocinho" continua com a aparência de "mocinho"; mas vira "bandido", para sobreviver na busca pela sobrevivência.

A Enfermeira ouve dizerem que: onde comem dois, comem dez e se preocupa com o estado nutricional dos membros dessa família, com a conseqüente vulnerabilidade às doenças ligadas à subnutrição, à desnutrição.

A Enfermeira ouve e compreende a frase da mulher abandonada pelo marido: "Q ue ele vá embora; vá não volte mais. Deus vai mi dá força prá trabalha, prá criá os filho que ele me deu. Não vou dá meus filhos prá ninguém".

Ouve e se preocupa porque nenhum dos membros dessa família tem ocupação qualificada ou fixa.

A Enfermeira vê crianças e jovens do sexo masculino ociosos, nas ruas e se preocupa. Onde conseguirão a "mesada" para irem à praia, ao cinema, para comprarem o tênis novo que viram na televisão, o relógio ou 0 rádio de pilhas, o óculos esporte ou o "walk-man". Onde conseguirão o recurso para irem junto com a turma, à noite, ao "agito jovem" das noites de sábado?

A Enfermeira assiste o "futebol de poeira" que acontece (de repente ou não) que mobiliza uma platéia de crianças, jovens, adultos e reflete:

Por que os outros jovens não estão aqui? Por que esses jovens não são postos-em-processo-de-grupo?

E descobre, que alguns dos que estão na "platéia", já jogaram e não o fazem mais porque "nunca mais agüentei jogar, depois que me acidentei numa partida... o pé dói quando eu ando, imagine correndo numa partida..."

A Enfermeira vê as meninas adolescentes de várias idades dentro de casa lavando, varrendo, cozinhando, cuidando das crianças menores e sofrendo... sofrendo quando a mãe as chama de "preguiçosas" se elas, às vezes, param o trabalho para pensar os sonhos de adolescentes, ou para se enfeitarem.

A enfermeira vê e se preocupa quando ouve a mãe dizer que as filhas são preguiçosas e "assanhadas" porque querem, à noite, ir até a pracinha. As meninas não podem ir, mas os rapazes, sim.

Preocupa-se com o destino dessas mulheres que nem bem o corpo lhes fala, à mulher em que se tornam, aprende com a mãe a submissão, a frustração, o despreparo para a luta pela sobrevivência no mesmo pé de igualdade que seu irmão, que seu namorado.

A Enfermeira sente o conflito:

- do jovem que não tem dinheiro para comprar "camisinha" para não pegar "doença do mundo".

- da mulher, cujo companheiro não tem dinheiro para Ihe comprar a pílula e se ela consegue "arranjar", "não se dá", porque o nervoso aumenta, a "gastura no estômago" aumenta e engorda.

- da mulher que arranjou um pouco de "leite e massa para "engrossar" a mamadeira da neném que nasceu há umas semanas e ouve o choro dos dois menores querendo, também o seu minguau.

- da mulher jovem que se olha no espelho e se vê envelhecida, sem os atrativos que tinha antes, sem ter dinheiro para comprar "enfeites"; sem poder comprar um fogão a gás ou o gás para o fogão; um liquidificador, uma geladeira, uma televisão.

- E fica agressiva com o companheiro que, enquanto ela passa anos e anos dentro de casa dando "um jeito" para ter o que dar de comer aos filhos, ele vai gastar, o pouco que ganha na semana, nos forrós.

- A Enfermeira, então, volta o olhar para as casas, deles e delas, e descobre quão instável é a situação dessas famílias, cuja moradia está assentada em terreno de "invasão".

Olha o ambiente em volta e percebe o potencial patogênico gestado no lamaçal, nos riachos criados pelas águas residuais dos barracos, nos esgotos de fábricas por onde passam adultos e onde as crianças brincam. Procura um chafariz e não encontra. 
Volta-se para o "mundo contíguo", o mundo diferente das outras famílias que têm outros tipos de preocupações porque estão inseridas na sociedade convencional e descobre:

- a solidariedade não institucionalizada, aquela que atinge em cheio às necessidades de busca no cotidiano das pessoas do "mundo vizinho", quando transitam diariamente, de um mundo marginal para o mundo da sociedade convencional no ir-e-vir que incomoda a muitos, comove a poucos e suscita ajudas.

- uma rede de instituições sócio-sanitárias com recursos humanos habilitados para atuarem a serviço da saúde e da educação e descobre que todos vão lá, onde estão os pobres e dizem:

"As crianças precisam ir para a escola precisam ser vacinadas, não devem andar descalças nesse lamaçal".

"A senhora precisa ter cuidado com as doenças que estão no lixo e na sujeira, com as moscas, com os ratos".

"é preciso ter cuidado com a cólera, fazer isto ou aquilo..."

"É preciso que a criança mame exclusivamente no peito, as crianças precisam comer..."

Geralmente, as mulheres ouvem e se calam; ouvem, tentam por em prática à sua maneira; ouvem e nada fazem porque nem sabem por onde começar... E nem entenderam o que lhes foi dito... $E$, geralmente as mulheres ouvem. E sentem vontade de entender melhor. E sofrem... Porque os maridos se zangam com seus pedidos. E as proíbem de ir à igreja (dizem que estão namorando com...) de ir ao culto protestante (porque falam besteira e querem mandar na vida deles e tirar dinheiro deles).

A autora, em suas ocupações e preocupações descobriu algumas possibilidades de ação para compartilhar, propondo-as para a enfermeira, atuando junto a grupos comunitários ou famílias.

\section{POSSIBILIDADES DE AÇÃO COMPARTILHADA}

Preparar-se para imergir no cotidiano da sobrevivência humana. Ter claro o propósito - trabalhar pela promoção humana em saúde.

R efletir, junto com essa clientela, sobre sua realidade, partindo de alguns princípios básicos - respeito à liberdade de pensar e de agir das pessoas; valorização dos processos cognitivos, da experiência pessoal no processo de atualização de si (ou processo de crescimento), da razão comunicativa, estimulando a competência comunicativa na busca do consenso sobre a verdade; aplicação dos princípios da interação simbólica no diagnóstico de situações interativas e na programação de estratégias de intervenção; aplicação dos princípios da dissonância cognitiva para identificar dissonância e ajudar no retorno à consonância. Identificar a rede social de apoio natural na área e tentar estabelecer mecanismos de articulação entre as duas redes - a institucional e a não institucional (ou natural).

A partir do contato com clientes (isolados ou não) identificar os "significativos" para eles ou os grupos de referência, para poder planejar as intervenções visando atingi-los em suas necessidades de saúde. $\mathrm{Na}$ identificação da rede social de apoio ou dos "significativos" é importantíssimo acumular o máximo de informações as quais podem ser coletadas, em todos os encontros, com a clientela que demanda a Unidade Sanitária ou durante as visitas domiciliares ou ida à rede de instituições sócio-sanitárias que atuam na mesma área.

Descobrir aquelas pessoas que se relacionam com o maior número de moradores da área, passa a ser uma meta importante da enfermeira de saúde pública. Discutir com elas o tema ou o problema-centro-deinteresse levantando-se suas cognições e confrontando-as entre si, para identificar dissonâncias e consonâncias é outro ponto no processo iniciado.

Dependendo da ideologia, das habilidades do mobilizador do grupo e de seus princípios éticos, essas primeiras reuniões, mais que uma curiosidade pessoal com vistas à manipulação, funcionará como o iniciar de um processo educativo visando instrumentalizar essas pessoas para a superação do pensamento ingênuo, da vulnerabilidade à manipulações de qualquer natureza. Essa instrumentalização deverá ser construída com a clientela. O referencial de Paulo F reire (1998) pode orientar essa caminhada.

Estimular a formação e a manutenção de grupos de suporte que discutam também as questões existenciais, visando a prevenção de quadros depressivos, cada vez mais comuns. 
Atividades em rede natural consideram-se aquelas que não agridem a cotidianidade dos moradores. Rastreando-se movimentos de "busca" e "encontro" (busca do trabalho e encontro desse trabalho ou não) serão facilitados os encontros entre os que ofertam e os que procuram algo, dentro da circunvizinhança.

Nesse empreendimento de trabalhar cognições/dissonâncias/ consonâncias e apoio social, o mobilizador assume o papel de articulador, mediador, coordenador, facilitador. São papéis que introduzem desafios que podem levar à desistência, se não houver por trás dessa pessoa, uma estrutura de apoio. No caso de formação e manutenção de redes sociais não governamentais ( cooperativas e outros empreendimentos), pode-se pensar numa programação conjunta com grupos religiosos organizados, grupos filantrópicos, recursos comunitários de saúde, educação e serviço social.

É fator primordial o exercício do falar, do expor opiniões de forma organizada, objetiva, racional. 0 treino do pensar logicamente, o respeito pelo argumento lógico do outro. As reuniões, portanto, serão exercício que valorizará o encontro entre pessoas que têm idéias a transmitir, comunicações a fazer, algo a ensinar, algo a perguntar ou a reivindicar. Tudo isso em função da promoção do entendimento sobre algo de interesse do ser humano em suas necessidades físicas e psicossociais fundamentais.

É importante, também, que a enfermeira se preocupe em estimular, direta ou indiretamente, o desenvolvimento da dimensão artística e das novas concepções sobre o trabalho entre a população da área, especialmente entre as crianças e jovens .

O propósito será sempre a formação de redes sociais de apoio recíproco, de exercício da comunicação racional e da afetividade, visando a promoção humana harmoniosa.

ABSTRACT: It is described the daily of lacking people in search of survival. It was observed that the hunger is the incentive of whole lacking people's process of searching and it is motivated by the dream of getting a better life. The obstacles are no or little schooling,qualification lack for working, difficulty at expressing their needs. The means are the willing body for working, the self-confidence, the faith in God and the hope for people's help. While they walk, they take decisions, they act, they dream of a better life. Walking and Finding can make the express of the self emerge (waking up the person for the experience of being-in-the-world-with-the-other-being and with the things) in the possibility of live in the authenticity of the being, according to Heidegger's point of view. In the group researched, I identified three manners of walking in the life: in the sense of the authenticity of the non authenticity in the possibility of "coming-to-being".

KEY WORDS: F amily; Nursing community; Community Medicina; Survival.

\section{REFERÊNCIAS BIBLIOGRÁFICAS}

1. AEBISCHER, Verena \& FOREL. (Org). Falas masculinas, falas femininas? S. Paulo : Brasiliense, 1991.

2. ARCHER, Sarah Ellen \& FLESHMAN, Ruth. Enfermería de salud comunitaria. Colombia, OPAS/OMS, 1977.

3. BERGER, Peter \& LUCKMANN, Thomas. A construção social da realidade. 4ed., Petrópolis : Vozes, 1978.

4. BOFF, Leonardo. Saber cuidar. Petrópolis : Vozes, 1999.

5. CHAUÍ, Marilena. Conformismo e resistência. S. Paulo : Brasiliense, 1986.

6. FERREIRA, Graciela B. La mujer maltratada. Buenos Aires : Sudamericana, 1994.

7. FESTINGER, Leon. Teoria da dissonância cognitiva. R io de J aneiro : Zahar, 1975.

8. FREIRE, Paulo. Pedagogia da autonomia. Saberes necessários à prática educativa. 7. ed., Rio de J aneiro : Paz e Terra, 1998.

9. GOODRICH, Thelma J ean et al. Terapia feminista da família. Porto Alegre : Artes médicas, 1990.

10. HEIDEGGER, I. Ser e Tempo, 1. 2. ed. Petrópolis : Vozes, 1988. p.11-178.

11. HELMAN, Cecil G. Cultura, Saúde \& doença. 2. ed. Porto Alegre : Artes médicas, 199.

12. INGRAM, David. Habermas e a dialética da razão. E dunb, 1993, p.1-19.

13. MELLO FILHO, J ulio de. Psicossomática hoje. Porto Alegre : Artes Médicas, 1992. p.1-191. 
14. PATERSON, J osephine G. \& ZDERAD, Loretta T. Enfermería humanística. México:Limusa, 1979.

15. SAINT-AR NAUD, Yves. A pessoa humana. S. Paulo : Loyola, 1979.

16. VARELA, Zulene Maria de Vasconcelos. Construindo no cotidiano da sobrevivência. Uma opção em Enfermagem de Saúde Pública. Tese Professor Titular. Fortaleza, 1992.

17. VARELA, Z.M.V.; SILVA, R. M.; BARROSO, M. G. Dimensões do cotidiano. Fortaleza : PÓS-GRADUAÇÃO/DENF/UFC, 1998.

18. VARELA, Z. M. V. Crônicas do cotidiano. In: ARRUDA, E.N.;GONÇALVES, L.H.T. Enfermagem e a arte de cuidar. Florianópolis : Editora da UFSC, 1999. p.131-143.

19. WRIGHT, Lorraine M. \& LEAHEY, Maureen. Nurses and families. A guide to family assessment and intervention. 2. ed. Philadelphia : F.A. Davis, 1994. 